\title{
Winter development of autumn sown white lupin: agronomic and breeding consequences
}

\author{
C Huyghe, J Papineau \\ INRA, Station d'Amélioration des Plantes Fourragères, 86600 Lusignan, France
}

(Received 14 June 1990; accepted 15 September 1990)

\begin{abstract}
Summary - Different genotypes of white lupin were studied for 2 consecutive years and at 6 sowing periods within each year. The mechanisms of frost resistance in lupins was studied. The thickness of the root parenchyma appeared to be a major factor of root frost tolerance. Despite genetic variability existing for this character, it was mainly influenced by the sowing period. Early sowings were necessary for good root frost tolerance. The components of the tolerance of aerial parts were shown to have high vernalization needs and high cold hardening ability. There was a large genetic variability for both characters. Screening techniques could readily be developed. Because of their high vernalization needs, frost tolerant genotypes tended to produce a high number of leaves on the main stem which meant increased risk of lodging. The prospects of improvement through the use of growth regulators and the breeding of dwarf genotypes are discussed.
\end{abstract}

Lupinus albus L / frost tolerance / vernalization / cold hardiness / root growth / breeding / culture technique

Résumé - Développement hivernal des lupins blancs en semis d'automne : conséquences agronomiques et possibilités de sélection. Différents génotypes de lupin blanc (Lupinus albus $L$ ) ont été étudiés 2 années consécutives avec 6 dates de semis par année. Des mécanismes de résistance au froid du lupin ont été analysés. L'épaisseur du parenchyme contical apparaît comme une composante majeure de la résistance au froid de la racine, résistance essentiellement mécanique, cet organe n'ayant pas d'aptitude à s'endurcir. La figure 1 montre que l'épaisseur du parenchyme cortical est plus important chez Lunoble, type d'hiver résistant au froid que chez TR2 bien que le diamètre total de la racine soit supérieur chez ce dernier, type de printemps, témoin de sensibilité. Bien qu'il existe une variabilité génétique pour la croissance racinaire, celle-ci et la résistance au froid potentielle sont surtout dépendantes des techniques culturales, et notamment des dates de semis (tableau 1). Les semis précoces sont une condition préalable à la bonne croissance racinaire. Des besoins élevés en vernalisation et l'aptitude à l'endurcissement sont les principales composantes de la résistance au froid des parties aériennes (apex et feuilles). La figure 6 montre que des besoins élevés en vernalisation, mesurés par une date de floraison tardive due à un semis de printemps, sont une condition nécessaire mais non suffisante à une bonne résistance au froid. Pour chaque composante, il existe une large variabilité. Les génotypes résistants au froid produiront un grand nombre de feuilles sur la tige principale, ce caractère étant également très influencé par la date de semis (fig 9). Ces génotypes auront aussi une floraison plus tardive pour partie en raison de l'importance de leurs besoins en vernalisation (fig 7). La possibilité d'une sélection entre croisements pour allier la résistance au froid à une certaine précocité de floraison est discutée. Les risques de développement végétatif excessif et de verse, liés au nombre de feuilles émises, pourraient être réduits par l'application de régulateurs de croissance ou l'obtention de génotypes courts.

Lupinus albus $L$ / résistance au froid / vernalisation / endurcissement / croissance racinaire / amélioration génétique / technique culturale 


\section{INTRODUCTION}

Autumn sowing of white lupin (Lupinus albus $L$ ) is often considered to be a good way to improve the yield of a lupin crop (Jambrina et al, 1988). It flowers 1 month earlier than the spring sown lupin and is, consequently, less susceptible to temperature and water stress during the flowering period which can substantially affect pod setting. It could then be an interesting way to improve the yield stability. Due to their long vegetative cycle, they build up a large amount of dry matter.

However, a winter crop must be reliable. It is therefore necessary to breed genotypes with high frost resistance, a main factor of winter tolerance, which can, with suitable agronomic techniques, overcome winter conditions.

In this paper, the winter growth of autumnsown white lupins was investigated in order to identify the mechanisms of frost resistance. Winter growth is thought to greatly influence the development of the plants during the following spring and this influence is discussed.

The consequences of high/low frost resistance levels on agronomic practices as well as breeding objectives and methods are discussed.

\section{MATERIALS AND METHODS}

The winter growth of the plants was studied in 2 growing seasons (1987-1988, 1988-1989) with 6 sowing periods per year (from the 15th of September until the 4th of November); 1 sowing period every $10 \mathrm{~d}$. The full trials were carried out in Lusignan (France). These times hedged the normal sowing time which is about the first half of October.

Three genotypes were investigated:

- TR2, which is an early flowering, spring type lupin with a low frost tolerance,

- ITA30, an italian population with a high frost tolerance which was collected near the Trasimene Lake (Italy) in 1985 (Papineau, 1987),

- Lunoble, a sweet (ie low alkaloid) winter lupin variety bred in France with a high vernalization requirement.

The root and apex of the plants were observed ev-ery 2 weeks throughout the winter, each datum was the average of the observations made on 6 plants per treatment (genotype $x$ sowing date). Three parts of the root were measured under the microscope: the total root diameter, the root parenchyma diameter and the central cylinder diameter. On the apex, the number of foliar primordia was counted and the date of emergence of the floral bud primordia (floral initiation) recorded as well as the final number of leaves produced by the main apex.
In order to study the relationship between vernalization requirements and flowering earliness, $F_{3}$ families originating from individual $F_{2}$ plants of 5 crosses were used. The 5 crosses included parents with a large range of variability both for winter tolerance and vernalization requirements.

The 1986-1987 winter was very cold and can be considered as a control for frost tolerance measured in the field. The results on winter growth are related to the behaviour of the plants in two 1986-1987 main experiments, 1 including 5 genotypes sown at 3 different times (23 Sept 1986, 7 Oct 1986, 31 Oct 1986) and 1 including 72 genotypes sown on the 10 Oct 1986 .

\section{RESULTS AND DISCUSSION}

\section{Root growth}

Figure 1 shows the growth of the different parts of the root over the autumn and winter period for plants sown on the 15th of September, 1987. The results from 2 genotypes are presented: TR2 and Lunoble, ITA30 behaving like Lunoble. This graph clearly shows that Lunoble produced a larger root parenchyma than the spring frostsusceptible genotype TR2, even if the total root diameter was larger for TR2 because of an increase in the size of the central cylinder.

The root size and structure were greatly influenced by the sowing period. In figure 2, the root characters on the 4th of January 1988 for the 2 genotypes and the 6 sowing dates are presented. It is obvious that, even for the frost tolerant genotype, the late sowing dates did not allow the root parenchyma to enlarge. The same features were observed the following year.

For these observations, the following hypothesis was proposed: the thickening of the root parenchyma could be a physical mechanism of frost tolerance of the root. Indeed, if as reported by Chen et al (1983) on winter cereals, the root is not able to cold-harden, other mechanisms must be responsible for the differences in root frost tolerance. Figure 3 shows the frost damage on the roots of Lunoble after a heavy freezing period during the winter of 1986-1987. The long period of frost, $21 \mathrm{~d}$, caused the soil to frost to -3.5 ${ }^{\circ} \mathrm{C}$ at $10 \mathrm{~cm}$ below the soil surface. This temperature, which was not very low compared with the $18^{\circ} \mathrm{C}$ recorded at the same time in the air, would explain why mechanical protection, without coldhardening, would be enough to avoid frost damage in the root. It is clear that there was a large husbandry effect and that early sowing resulted 


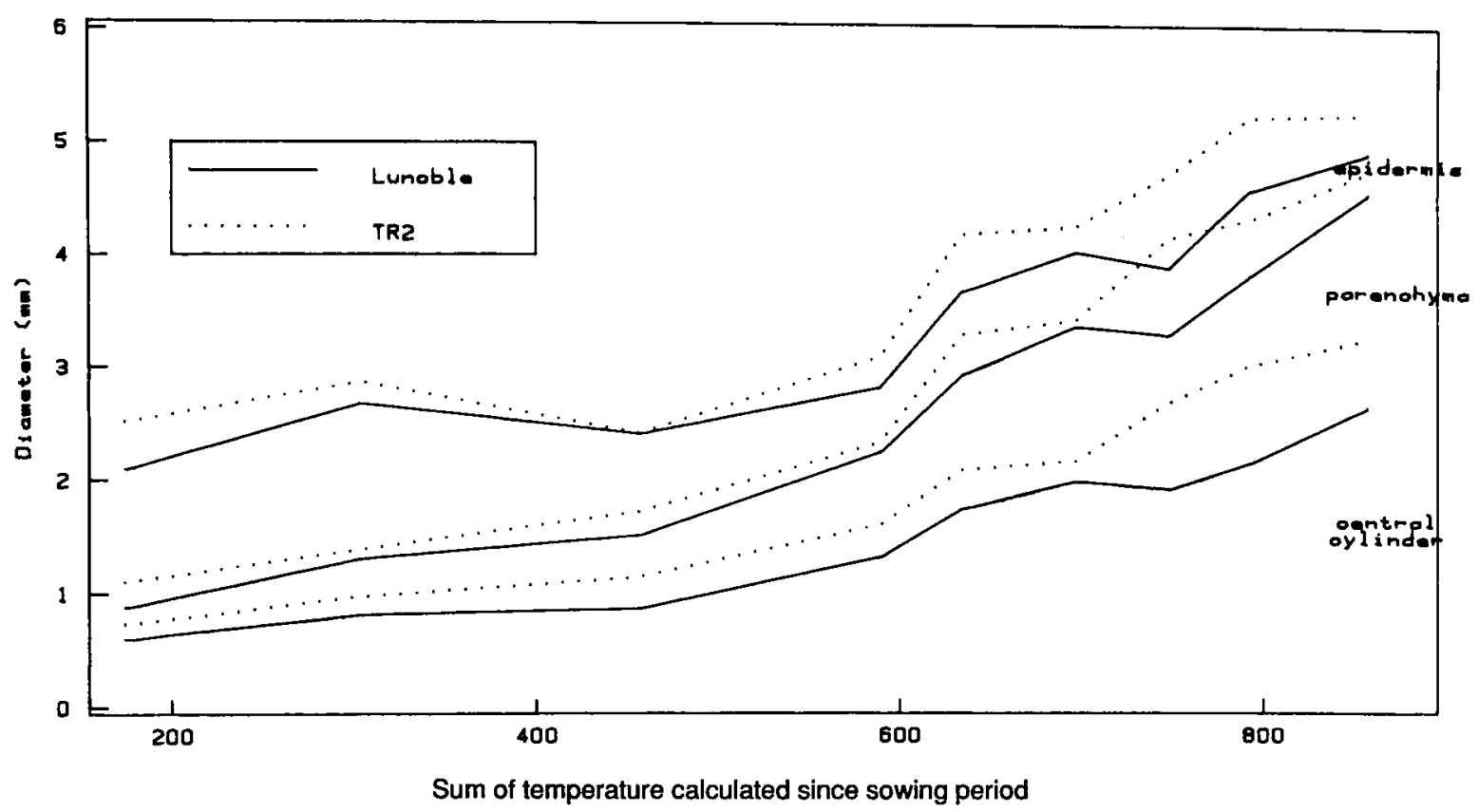

Fig 1. Comparative winter root growth of TR2 and Lunoble sown on the 15th of September 1987.

in a better root frost tolerance than a late one; the latest even leading to full destruction of the crop. This could be related to the lack of growth of the root parenchyma in seedlings originating from late sowings.

The origin of the thickening of the root parenchyma was not investigated. However, the increase in the number of cells seemed to be a major factor of this phenomenon.

From these results, it appears that, whatever the genotype, early sowing is necessary to allow the genotypes to express their potential root frost tolerance. There is genetic variation for the root damage after heavy frost (table 1). This could also be explained by the variation for the root parenchyma thickness. The available genetic variability must be investigated extensively and used in lupin breeding programme. However, screening techniques for root frost tolerance still have to be developed. The parenchyma thickness seems to be an appropriate criterion but it has implications in terms of work load. The

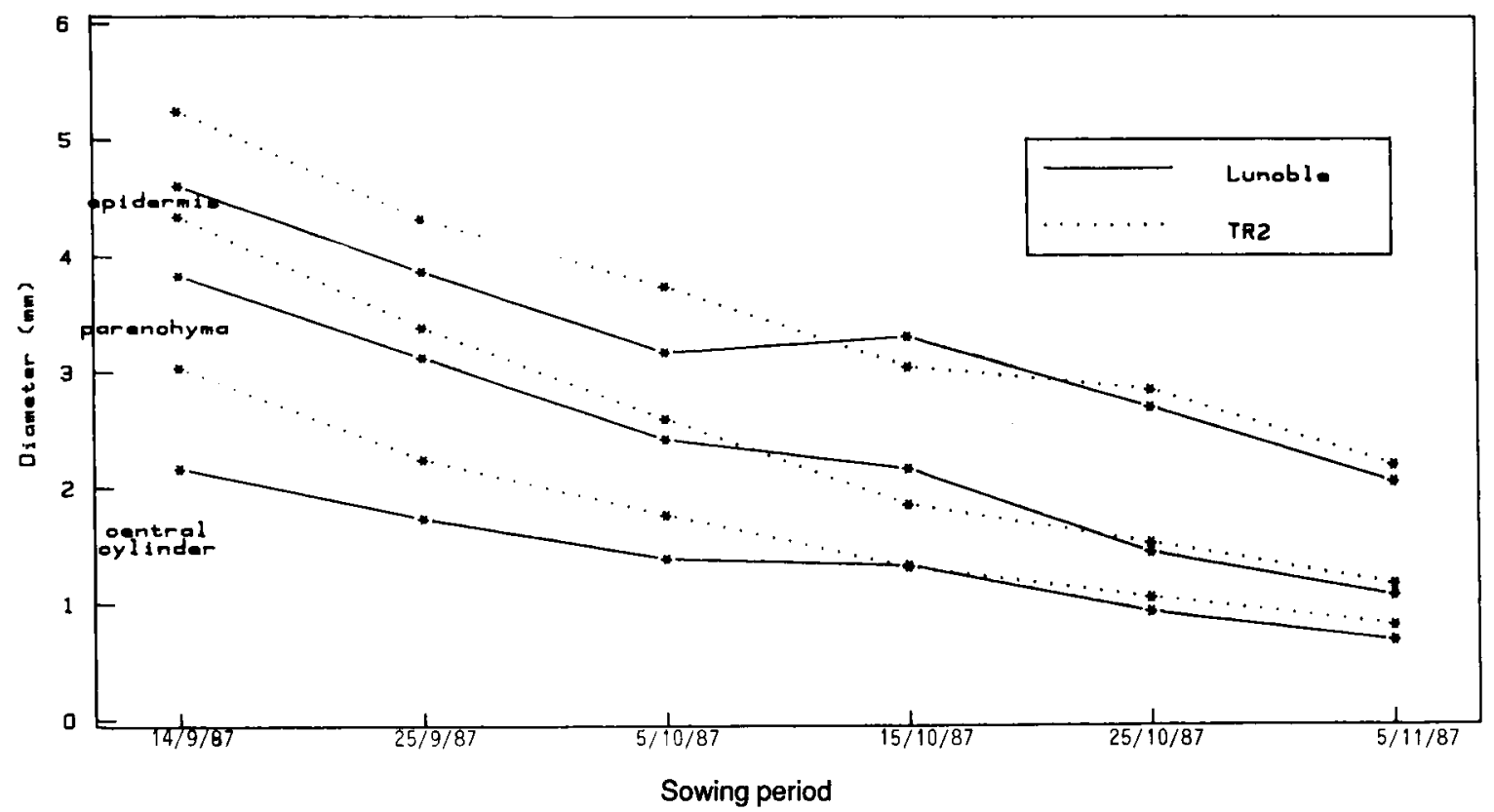

Fig 2. Structure of the roots of TR2 and Lunoble on the 4th of January 1988 in terms of sowing period. 


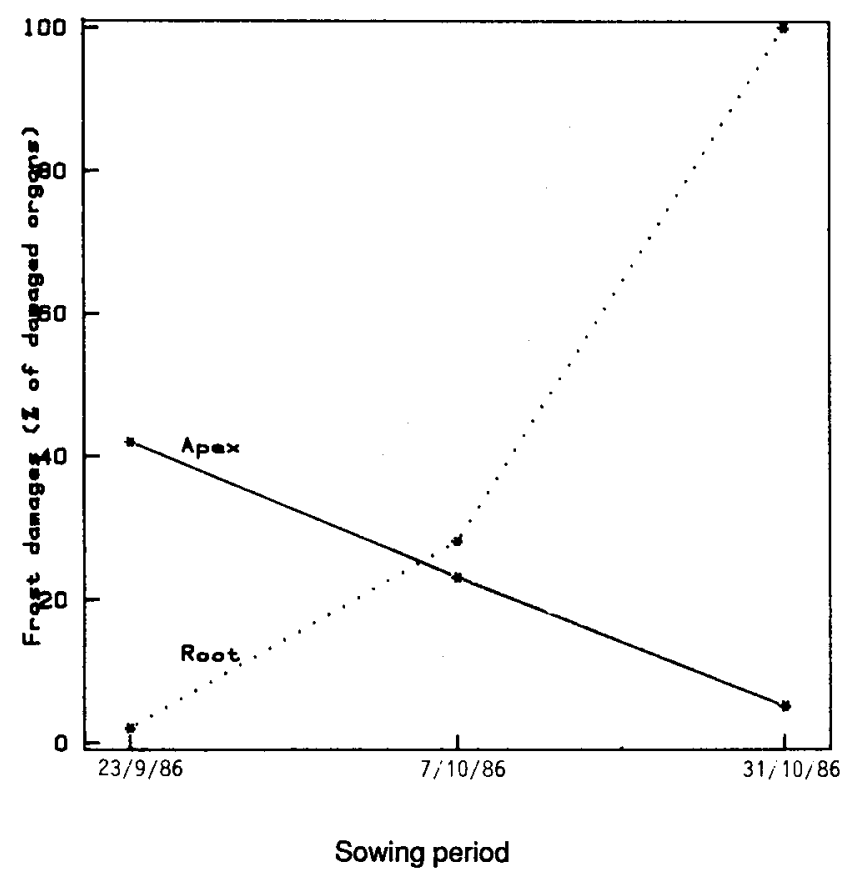

Fig 3. Effect of the sowing period on frost damage during the winter 1986-1987.

total root diameter cannot be used because the epidermis tends to peel. This could induce major errors of measurement.

\section{Apex growth}

The apex of the main stem produces leaf primordia during its vegetative period and then floral bud primordia after vernalization (fig 4). The number of leaves produced by the apex and the date when the first floral buds appear are consequences of the required amount of vernalization. The periods when the first floral buds were seen on the plants of the different genotypes, sown at different times are shown in figure 5 .

Table I. Root damage recorded during the winter 1986-1987 on different genotypes and at different sowing period (in \% of the number of emerged plants).

\begin{tabular}{lccc}
\hline Genotype & $\begin{array}{c}\text { Date 1 } \\
(23-9-1986)\end{array}$ & $\begin{array}{c}\text { Date 2 } \\
(7-10-1986)\end{array}$ & $\begin{array}{c}\text { Date 3 } \\
(31-10-1986)\end{array}$ \\
\hline C8 & 12.7 & 64.9 & 100.0 \\
C52 & 10.3 & 60.0 & 100.0 \\
C131 & 11.9 & 59.3 & 100.0 \\
C168 & 3.6 & 28.6 & 100.0 \\
Lunoble & 2.7 & 35.0 & 100.0 \\
\hline
\end{tabular}
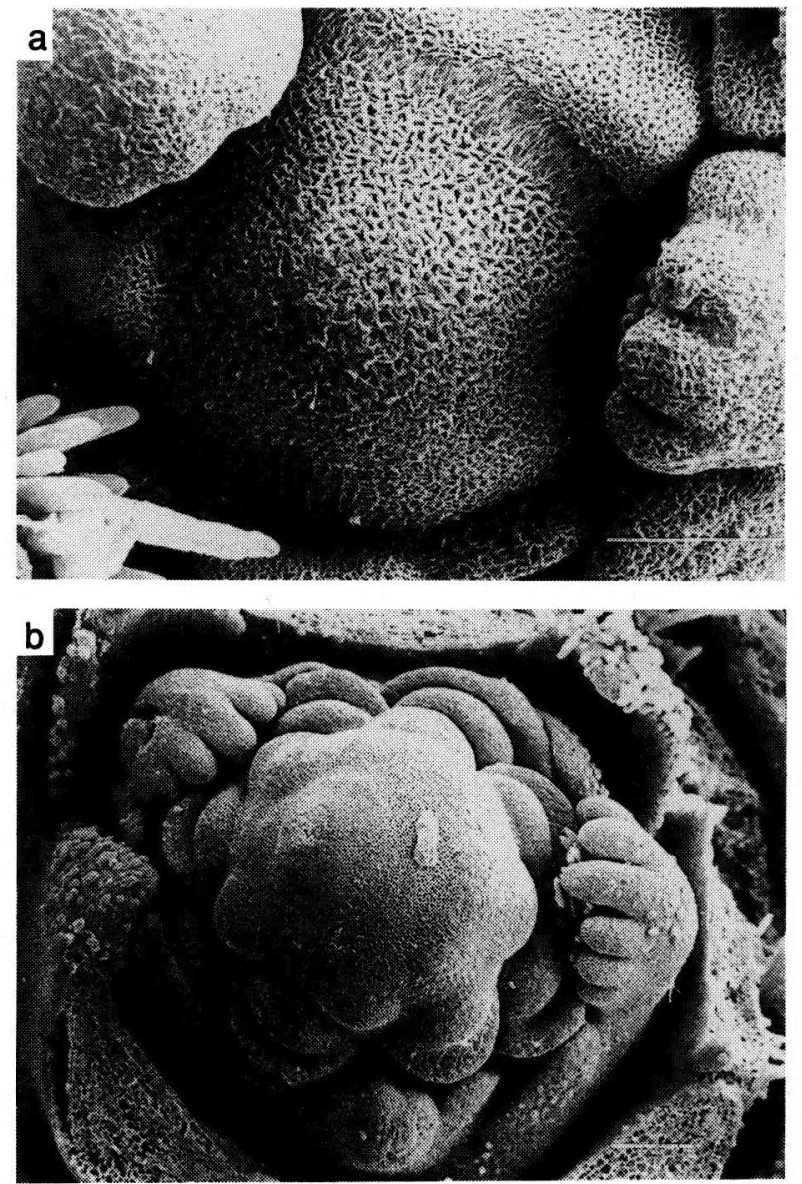

Fig 4. Apices of plants of ITA30 sown on the 15th of September 1987 during the winter (bars $=100 \mu \mathrm{m})$. a) Vegetative apex (4 janvier 1988), b) Floral apex (18 janvier, 1988).

For all genotypes, the sowing date greatly influences the time when the apex turned floral, this change occurring later for the late sowings. This could be the origin of the difference in apex damage due to the frost on Lunoble in 19861987 (fig 3). There were more damaged apices

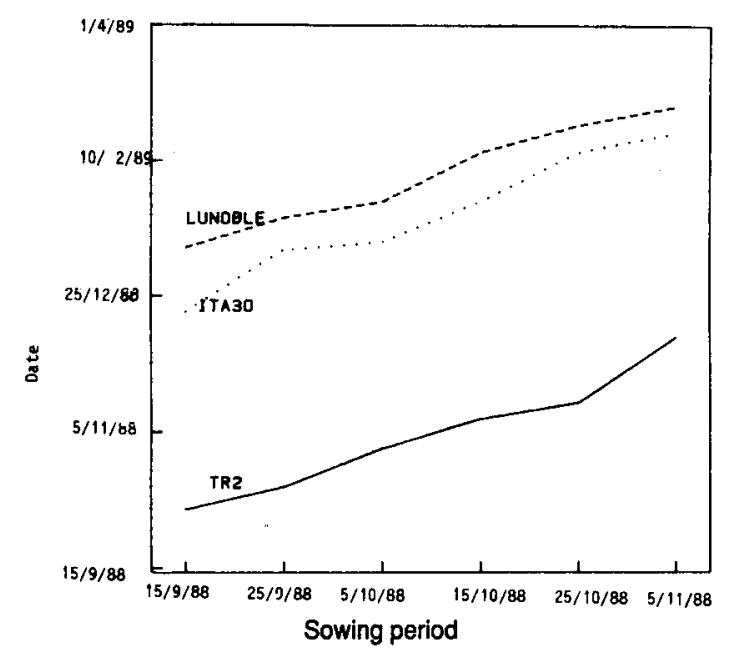

Fig 5. Dates when the apex turned floral in terms of the genotype and sowing period (winter 1988-1989). 
after an early sowing, but such damage was not always lethal, plants being occasionally able to recover by growth of lower branches.

There is a large genetic variability for vernalization requirements. This ranged from the early spring types without any requirement, such as TR2, to very late winter types, as Lunoble. All the winter types are characterized by important vernalization requirements which give the plant a typical winter growth characteristic: a long rosette stage. This stage lasts until the apex flowers.

The vernalization needs can be estimated by the flowering period when sown in spring. Indeed, in such cases, the plants elongate and flower without any delay after being vernalized.

These requirements appear to be an important factor of the apex frost tolerance. As shown in figure 6 , there is a relationship between the vernalization requirements and the proportion of frost survival, in this case, after the 1986-1987 winter. High vernalization requirements are a prerequisite condition for high frost tolerance, all the genotypes being in the bottom right part of the graph. However other factors seem to influence tolerance. Root size certainly does, but most is due to the cold hardening ability.

For the frost tolerance of the lupin apex the following mechanism is proposed: once floral, the apex begins to enlarge very quickly and the stem develops the ability to elongate. These 2 modifications increase susceptibility to frost, even if mild, because both large floral apices and young

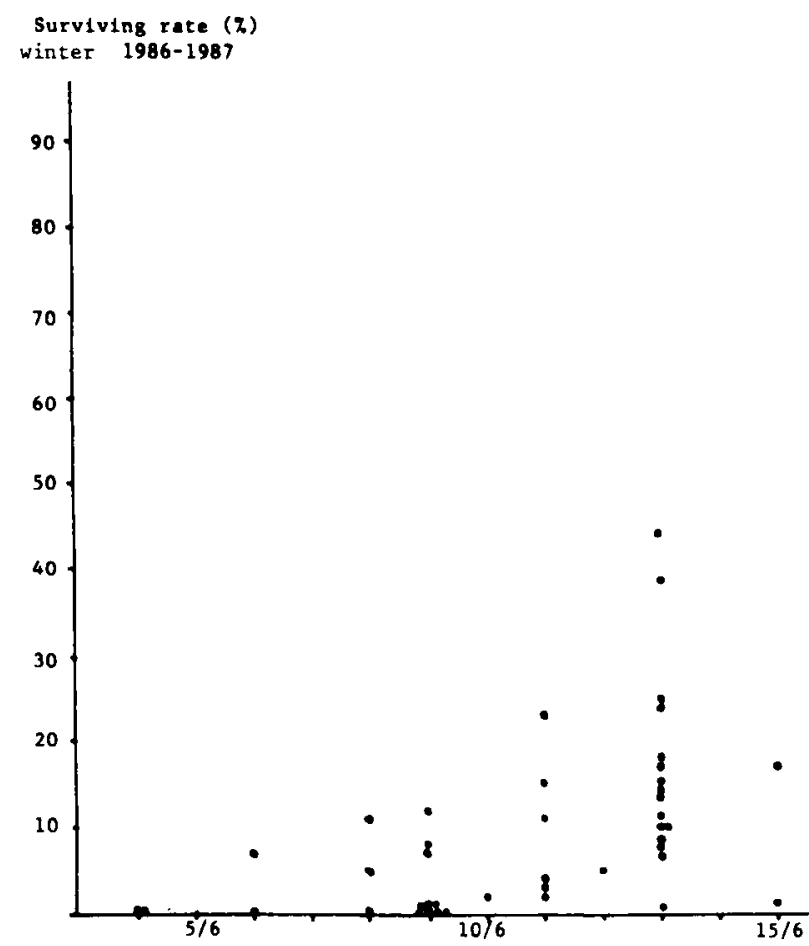

stems are fragile organs. Such developments could also interfere with the cold hardening process. Lalk and Dorffling (1985) showed that ABA (abscisic acid) was involved in the chain of events leading to frost resistance in leaves of wheat. In Medicago sativa, Waldman et al (1975) suggested that cold hardening was controlled by the balance of growth regulators, particularly ABA-GA3, a high ratio being required for good hardening and consequently a high cold hardiness. In the winter lupin, when the apex becomes floral and the stem begins to elongate, the GA3 (gibberellic acid) content rises and consequently it is very likely that the $A B A$ GA3 ratio decreases, hence reducing, or even preventing, any cold acclimation. The differences in frost tolerance which can be seen between genotypes with similar vernalization requirements could be due to different ABAVGA3 ratios during the rosette stage. In addition to the evaluation of the vernalization requirements, the cold hardening ability must be measured in order to obtain a good estimation of the potential frost tolerance of a genotype. A screening test in controlled conditions was defined in order to measure tolerance without interfering with the vernalization requirements or root growth.

The breeding of winter tolerance will lead to the selection of genotypes with high vernalization needs. It is important to know to what extent this will influence the earliness of flowering in the autumn sown lupin, this earliness being one of

Fig 6. Relationship between the vernalization requirements and the frost tolerance as seeen during the winter 1986-1987. 
the advantages of this crop. The $F_{3}$ progenies, each originating from individual $F_{2}$ plants of 5 crosses, were studied. They were sown both in winter for measuring their flowering earliness and in spring to measure vernalization requirements. The regression slopes relating the 2 characters are similar for the 5 crosses (fig 7), the correlation being highly significant in all cases, ranging from 0.636 (50 df) to 0.828 (49 df). The correlation between the vernalization requirements and the earliness of flowering suggests that once the apex is floral, the time of flowering is controlled by the total amount of temperature (expressed in ${ }^{\circ} \mathrm{C} \times \mathrm{d}$ ) which allows the elongation of the stem and the development of the inflorescence. Apparently, the day length does not interfere with this process as is the case for other legumes. This could be due to the Mediterranean origin of the white lupin where the winter lupins experience conditions similar to the French ones, especially for the day lengths.

These correlations would suggest that the plant breeder should first select for a minimum level of vernalization requirements which are appropriate to the level of frost resistance according to the region where the lupins are to be grown. This selection could be on a progeny basis, ie between-cross selection. Then, among the progenies of the best crosses, he could select both for frost tolerance and earliness of flowering.
The number of leaves produced by the main apex will depend on the vernalization requirements of the genotype and the sowing time. Figure 8 shows the increase in the number of leaf primordia in terms of cumulative sum of temperatures, with a threshold at $3{ }^{\circ} \mathrm{C}$, since the sowing (on the 15th of September 1988). There is a regular increase until the curves rise to a plateau when the apices have turned floral. This occurred very quickly for the spring type and late for both winter types. Their rising curves were fairly similar which suggests that both genotypes' apices produce new primordia with the same frequency. The only difference is in the final number of primordia, Lunoble has more because of its higher vernalization requirements.

Figure 9 shows the final number of primordia for the 3 genotypes and the 6 sowing periods in the autumn of 1988. If the number of primordia was constant for the spring genotype whatever the sowing period, vernalization occurring very quickly, both winter genotypes showed an important decrease. Lunoble produced 34 leaves when sown on the 15th of September 1988 and only 17 when sown on the 5th of November, 1988. The number of leaf primordia produced by the main stem will partly determine the height of the main stem. The main stem height of isolated plants was correlated with the number of leaves on this stem [0.68 HS) over the 2 experimental years]. The size increased with the number of leaves. When grown at higher densities with the

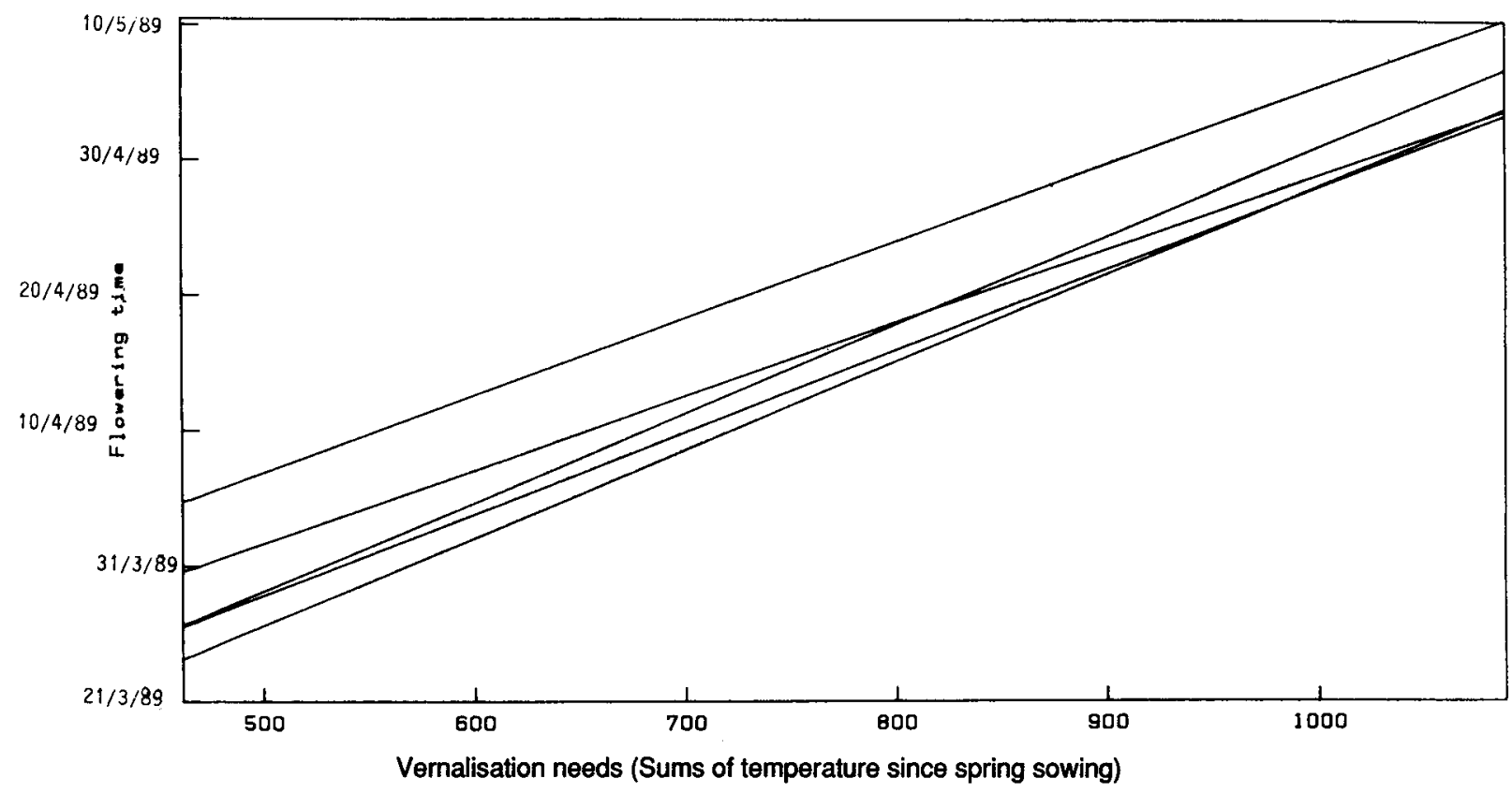

Fig 7. Relationship between the vernalization requirements and the earliness of flowering among the $F_{3}$ progenies of 5 crosses. 


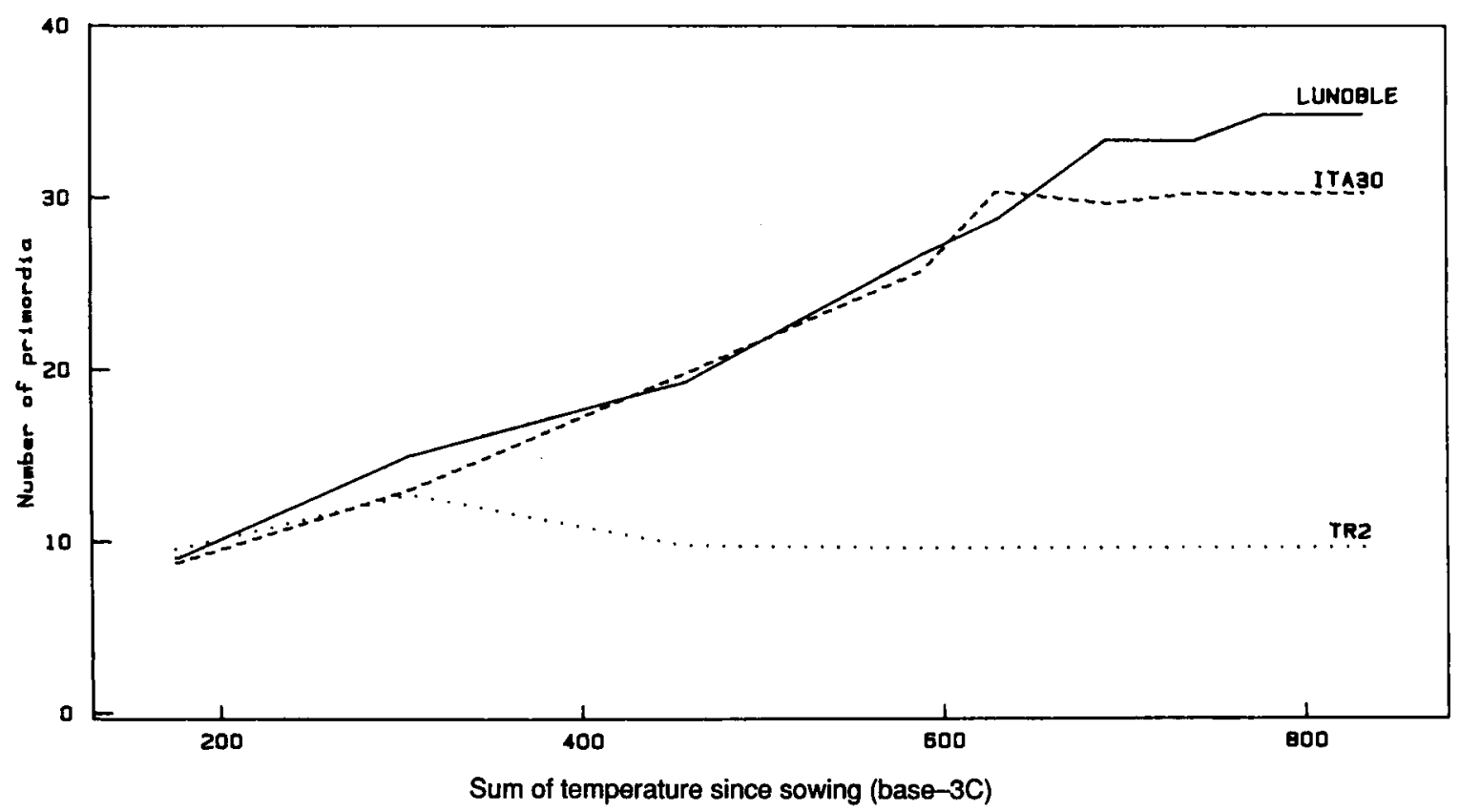

Fig 8. Evolution of the number of leaf primordia over the winter (sowing period: 15 Sept 1988).

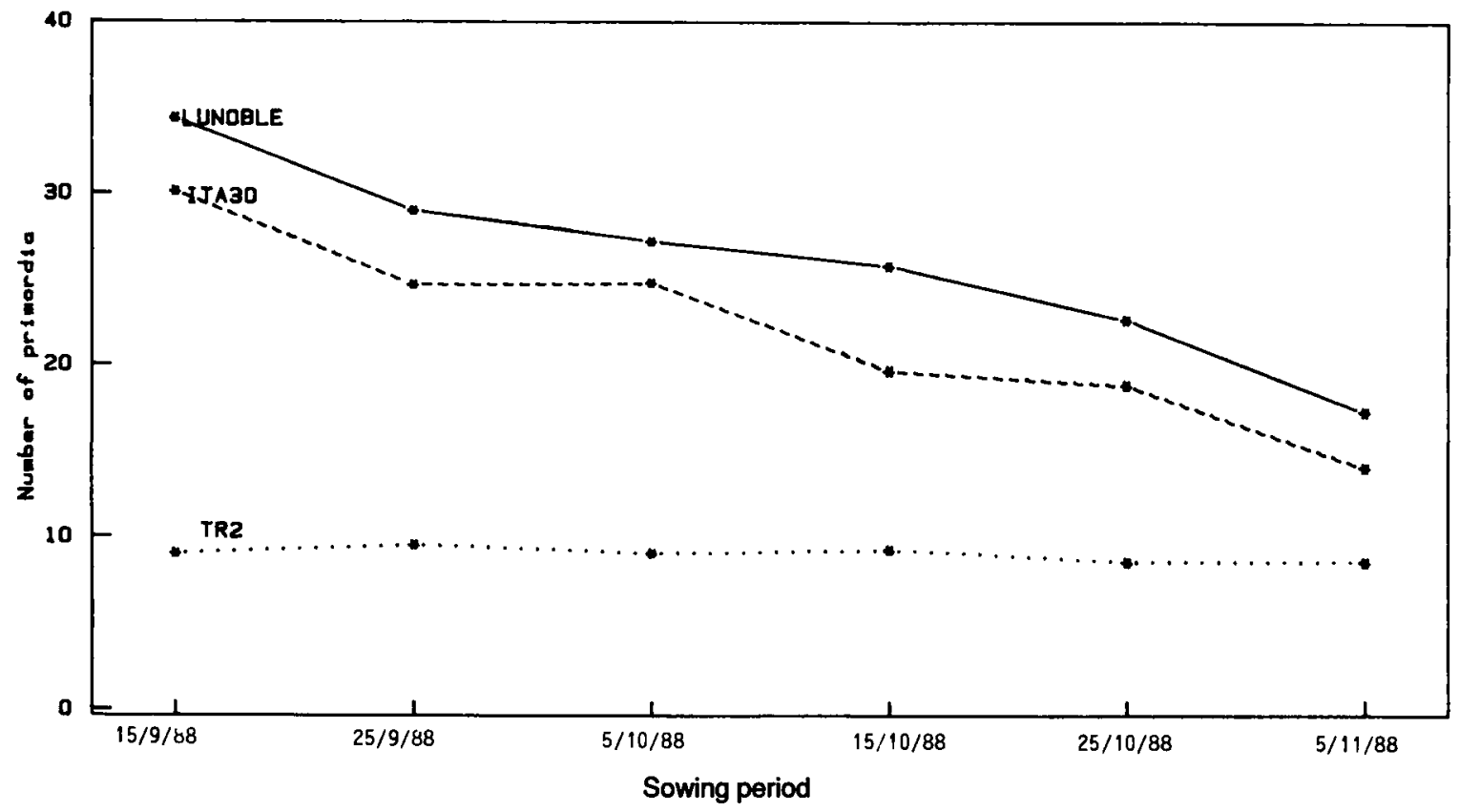

Fig 9. Final number of leaves produced by the apex.

inherent etiolation, the risk of lodging become higher when the number of leaves increases.

For every region where winter lupins are to be grown, the optimum sowing period should be studied. On the one hand, it must allow good root growth so that the root can bear the frost which might occur. On the other hand, sowing must not be too early in order to avoid both an early floral apex and an excessive vegetative growth resulting in subsequent lodging. To solve this problem, there are various possibilities. One is to use growth regulators. Some triazoles applied at an early stage have given promising results (Billot, unpublished data). Another possibility is to look for dwarf types which would allow early sowing without any later disadvantage. Some genotypes 
with new and promising growth possibilities are presently under study.

\section{CONCLUSION}

Results obtained in this study open the way for winter lupin to become a promising crop in the future. Appropriate studies could define the optimum sowing period for any region so that the root growth is maximised without an excess of vegetative development. The mechanisms of frost resistance of the whole plant were studied and hypotheses for root and aerial part resistance are proposed. This paves the way for new methods in breeding. There is a large genetic variability for the three main components of frost tolerance: root growth, vernalization requirements, and cold hardening ability. Both breeding aims and screening techniques can now be defined.

At the same time as improving frost tolerance, breeders will have to deal with other problems: genotypes with high vernalization requirements tend to flower late, and above all, in order to obtain a reliable crop, optimum sowing periods will be quite early so that plants will produce many leaves and grow well during the spring and summer.

\section{ACKNOWLEDGMENTS}

The authors thank JM Pissard for helpful technical assistance and the UNIP and GIE Lupin for financing this study.

\section{REFERENCES}

Chen T HH, Gusta LV, Fowler DB (1983) Freezing injury and root development in winter cereals. Plant Physiol 73, 773-777

Jambrina JL, Crespo MC, Blanco R (1988) The white and narrow leafed lupin breeding for the central western region of Spain. Proceedings of the 5 th International Lupin Conference, Poznan Poland, 5-8 July, 146-155

Lalk I, Dorffling K (1985) Hardening, abscisic acid, proline and freezing resistance in two winter wheat varieties. Physiol Plant 63, 287-292

Papineau J (1987) La résistance au froid des lupins blancs (Lupinus albus L). Variabilité génétique, sélection, création de matériel végétal doux. Rapport d'Ingénieur diplômé par l'État, ENSAM Montpellier, $67 p$

Waldman M, Rikin A, Dovrat A, Richmond AE (1975) Hormonal regulation of morphogenesis and cold resistance. II. Effect of cold acclimation and of exogenous abscisic acid on gibberellic acid and abscisic acid activities in alfalfa (Medicago sativa $\mathrm{L}$ ) seedlings. J Exp Bot 26, 95, 853-859 